Katarzyna Mulet

\title{
Retoryka popkultury w Pięknych dwudziestoletnich Marka Hłaski
}

Powieść Piękni dwudziestoletni Marka Hłaski z pewnością można nazwać fabularyzowaną opowieścią o jego własnym życiu, ale zważywszy na jej filmową tematykę i język, wydaje się, że znacznie bardziej przypomina ona jednak gotowy do odegrania scenariusz, w którym główną rolę jego autor powierzył samemu sobie. Ta „automitologia” pisarza, jak nazywa ją Lech Kurpiewski [1986: 19], jest zarazem świadectwem jego pragnień i fascynacji względem rozmaitych bohaterów popkultury, jacy stają się dla niego modelami ciekawych zachowań, a przede wszystkim niezapomnianych wypowiedzi ${ }^{1}$. Hłasko odrzuca w niej możliwość wzorowania się na „gigantach” literatury takich jak Fiodor Dostojewski, William Faulkner czy Ernest Hemingway, bo okazali się oni bezsilni w ekspresji uczuć mieszkańców tandetnego świata [por. Pyszny 2007: LXVI; zob. Jarzębski 1984: 298-300]. Zamiast tego próbuje naśladować idoli masowej publiczności, zaczynając od kreskówkowej postaci psa Goofy’ego, a kończąc na aktorach tej wielkości, co James Dean, Marlon Brando oraz Humphrey Bogart, którzy znacznie lepiej odpowiadają potrzebom nowej cywilizacji, gdzie liczą się przede wszystkim prostota, uniwersalność i efektowność.

Nie dziwi więc fakt, że poszukując swych bohaterów Hłasko w pierwszej kolejności zwrócił uwagę na kolebkę popkultury, czyli Stany Zjednoczone. W czasach komunizmu, gdy powstawali Piękni

1 W innym artykule analizującym tę samą powieść Marka Hłaski posłużyłam się teorią mimetyczną René Girarda w celu ukazania przyczyn i skutków imitacyjnej postawy pisarza [zob. Mulet 2012: 237-252]. 
dwudziestoletni, w zasadzie wszyscy Polacy fascynowali się Ameryką i wszystkim, co stamtąd pochodziło. Stanowiła ona bowiem ich wyobrażenie raju, w którym powszechnie panują wolność i dostatek. W przypadku pisarza ten rodzaj nieszczęśliwej miłości skrystalizował się w szczególności wokół kwestii związanych z kinem i grą aktorską. Prawdopodobnie to właśnie zainteresowanie kulturą Stanów Zjednoczonych przyczyniło się do „filmogenności” prozy Hłaski, a więc jej przesycenia dialogami, scenkami i sytuacjami gotowymi do odtworzenia przed kamerą. Jednak jego fascynacja zachodnimi idolami miała również swoje drugie dno, ponieważ zaważyła na sztuczności i retoryczności stylu Pięknych dwudziestoletnich i, wbrew intencjom samego autora, stała się jednym z powodów, dla których część krytyków posądzała go o brak autentyzmu oraz przerysowanie rzeczywistości ${ }^{2}$. Tymczasem wydaje się, że przesada i hiperbola czy nawet groteska i persyflaż były dla pisarza wyłącznie sposobami na wyrażenie jego subiektywnych przemyśleń i odczuć, tak jak w przypadku opisu pewnej wystawy, jaka odbyła się w Warszawie:

W roku 1952 urządzono w Arsenale wystawę pod dramatycznym tytułem: „Oto Ameryka”. Nazbierano do cholery i trochę eksponatów: pistolety dla szpiegów, bomby napalmowe, komiksy zrobione z Braci Karamazow i trupy jakichś Murzynów. Skutki wystawy były straszliwe; godzinami czekało się w kolejce na wejście, gdyż ludzie chcieli zobaczyć cokolwiek amerykańskiego; ludzie chcieli zebrać jakiekolwiek informacje o kraju czterdziestu ośmiu gwiazd; ludzie chcieli przez chwilę popatrzyć na rzeczy zrobione przez ludzi zza oceanu, którzy nigdy im nie pomogą. Jest to miłość nieszczęśliwa; miłość bez cienia wzajemności; i już chyba ostatnia [Hłasko 1999: 85].

Zacytowany fragment Pięknych dwudziestoletnich pokazuje również, że Hłasko opiera swój przekaz przede wszystkim na prostym, potocznym języku, tak zwanym „stylu mówionym” [Wasilewski 1991: 25], jaki ma szansę trafić do szerokiej rzeszy odbiorców. Zabieg ten wiąże

2 Wśród nich można wymienić między innymi Stanisława Stabro, Michała Komara czy Artura Sandauera [por. Pyszny 2007: XLIX]. 
się bezpośrednio z postawą niezgody pisarza wobec pompatycznego i zideologizowanego charakteru utworów socrealistycznych [zob. Pyszny 2007: XXXVIII ], a tym samym wpisuje się we wzorzec osobowy wiecznego buntownika, który autor powieści dzieli razem z Jamesem Deanem $^{3}$. Jednak całkowite odrzucenie językowej jednolitości i jednoznaczności przez Hłaskę powoduje również, że jego powieść staje się mieszanką różnych dialektów, gwar i żargonów, a obszar ich rozpiętości wyznacza pole intertekstualnych nawiązań pisarza, obejmujących zarówno dialogi kreskówkowych postaci, jak i rozmowy filmowych gangsterów. Wielogłosowość jako cecha konstytutywna Pięknych dwudziestoletnich sprawia, że zaczynają łączyć się ze sobą potoczny język i literacki chwyt [por. Wielopolski 1987: 162].

Najlepszym przykładem dla takiej sytuacji jest aforystyczność niektórych wypowiedzi kinowych bohaterów, jakie Hłasko włącza do swojej powieści na zasadzie aluzji, stylizacji, parafrazy bądź cytatu. Wśród nich nie brakuje przede wszystkim filmowych kwestii Bogarta, który nie tylko jest ulubionym aktorem pisarza, ale również stanowi dla niego wzorzec przekonującej gry opartej na ekspresyjnym dialogu. Autor Pięknych $d w u-$ dziestoletnich zwraca bowiem w szczególności uwagę czytelnika na sposób mówienia gwiazdy amerykańskiego kina, akcentując jego zmienny tok wypowiedzi, pauzy, zacięcia przy krótkich zdaniach, to znów „wyszczekiwanie” tych dłuższych, a wreszcie udawane zrezygnowanie i zmęczenie podczas całego dialogu [zob. Hłasko 1999: 124]. W pewnym momencie Hłasko posuwa się nawet do przytoczenia niektórych tricków i gestów Bogarta ${ }^{4}$, ujawnionych przez aktora już wcześniej w wywiadzie z dziennikarzami, co z jednej strony obnaża sztuczność i retoryczność

3 „Peryfraza »Hłasko - komunistyczny James Dean «, ukuta przez zachodnią prasę po wyjeździe pisarza z kraju, przylgnęła do niego na trwałe" [Pyszny 2007: LXXIV].

4 „Na pytanie dziennikarzy, o czym myśli wtedy, kiedy twarz jego przybiera wyraz zrezygnowania i zmęczenia, Bogart odpowiedział, że nigdy w ogóle nie myśli o niczym, a dziwaczną ekspresję twarzy uzyskuje dzięki prostemu trikowi: otóż prawy but zakłada na lewą nogę i odwrotnie [...]" [Hłasko 1999: 123]. 
całej jego filmowej kreacji, ale $\mathrm{z}$ drugiej staje się kolejnym powodem podziwu pisarza dla tego gwiazdora, który za pomocą swego wyznania paradoksalnie dał dowód szczerości swojej gry.

Podobny zabieg przeprowadza zresztą w Pięknych dwudziestoletnich sam autor powieści. Chodzi tu mianowicie o konsekwentne ujawnianie przez niego źródeł językowych zapożyczeń, które bezpośrednio łączy się z prowadzoną przez niego grą [por. Mulet 2012: 244]. Zastosowanie przez Hłaskę tego samego chwytu co Bogart spełnia w jego utworze co najmniej kilka funkcji. Filmowa proweniencja dialogów przede wszystkim sugeruje, że pisarz bynajmniej nie porusza się w sferze swego realnego życia, ale operuje tak zwanym „prawdziwym zmyśleniem” [Hłasko 1999: 161], czyli po prostu występuje w zaprojektowanej przez siebie roli. Sztuczność języka osadzonego w retorycznej stylistyce dodatkowo podkreśla autokreacyjny wizerunek autora, a zarazem głównego bohatera swojej powieści, który paradoksalnie upatruje w nim skuteczności swego aktorskiego oddziaływania. Wreszcie Hłasko komunikuje nieuchronność posługiwania się cudzą mową w literaturze za pomocą transpozycji „eleganckiej” potoczności z tekstów popkultury [Galant 1996: 92] do swojej powieści, co staje się jego podstawowym narzędziem w walce z zakłamaniem i tandetą otaczającego go świata zdegenerowanych wartości.

Okazuje się więc, że mechanizm stylizacyjny, jaki determinuje zarówno formalną konstrukcję, jak i warstwę semantyczną Pięknych $d w u d z i e s t o l e t n i c h$, bierze się z silnego przeświadczenia pisarza o nieautentyczności i wtórności stosunków międzyludzkich, a jedną z konsekwencji takiego poglądu staje się wymieszanie w jego powieści tego, co realne i tego, co fikcyjne, prawdziwego życia i wymyślonego filmu, rzeczywistych ludzi i gwiazd aktorstwa. Przykładem takiej sytuacji jest porównanie pułkownika UB Jacka Różańskiego do jednej z najbardziej cenionych przez Hłaskę ikon amerykańskiego kina:

Interesowali mnie zawsze oprawcy; ciekaw byłem, jak wyglądają ci, którzy innym ludziom wyrywają paznokcie i włosy i łamią żebra. Ułatwiono mi kontakt z Różańskim i poszedłem do niego. Był to pan o wyglądzie fanatyka, i o tym wiedział. Mówił interesująco, jego aktorstwo było do- 
bre i gdybym chciał porównać go z jakimś aktorem, porównałbym go z Marlonem Brando, który także mówi bardzo wolno, nieefektownie, męczy się jakby w czasie wypowiadania dialogu, co stwarza złudzenie, że Brando nie mówi tekstu napisanego uprzednio przez Rappaporta, lecz że szuka własnych słów i własnych sformułowań [Hłasko 1999: 32].

Na podstawie tego przykładu uwidacznia się również stosunek au-

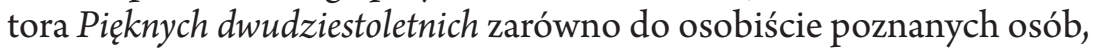
jak i do odległych filmowych sław. Jedni i drudzy pełnią bowiem w jego powieści wyłącznie funkcje egzemplifikacyjne, służą w związku z tym obnażeniu sekretów gry, pokazują jak naturalnie wypowiadać dialog i stosować profesjonalne aktorskie tricki, ale w szczególności uczą pozornie głębokiego przeżywania roli, które stanowi nadrzędny cel stosowanej przez Hłaskę retoryki popkultury. Jerzy Jarzębski stwierdza nawet, że podobny stosunek pisarz przejawia względem filmowych fabuł: „lekceważy je głęboko, tak iż nawet nie używa imion bohaterów, tylko nazwisk aktorów, bo akcja i treść tej »piekielnej szmiry« [mowa tu o Casablance - K. Mulet] jest zupełnie nieważna” [Jarzębski 1984: 302]. Cała uwaga autora Pięknych dwudziestoletnich skupia się więc jedynie na powierzchowności słów i zachowań jego idoli, którzy, choć pozbawieni „psychologii” i „wnętrza” [Jarzębski 1984: 305], emanują jednak retoryczną siłą, którą pisarz wykorzystuje w powieści.

Najbardziej skrajną realizacją tej praktyki Hłaski jest jego wzorowanie się na postaci Goofy'ego ${ }^{5}$. Ten kreskówkowy pies jest jedną z wersji wizerunku losera, jakie można odnaleźć w utworze Piękni dwudziestoletni. Goofy, podobnie zresztą jak Bogart, jest tam „przegrywaczem", czyli bohaterem skazanym na klęskę pomimo swoich najlepszych intencji i wysiłków ${ }^{6}$. Jednak o ile amerykański aktor stanowi dla

5 W Pięknych dwudziestoletnich Hłasko parafrazuje słynne stwierdzenie Gustawa Flauberta mówiąc o sobie: „Goofy, to ja” [Hłasko 1999: 76].

${ }^{6}$ Jerzy Jarzębski podobnie pisze o głównym bohaterze Pięknych $d w u-$ dziestoletnich: „Bohater Hłaski mógłby o sobie powiedzieć, że »kłopoty to jego specjalność «: trapi go nieodmiennie jakaś idée fixe, która nie pozwala mu żyć »normalnie « i pcha w sytuacje bez wyjścia” [Jarzębski 1984: 300]. 
pisarza obiekt prawdziwej fascynacji, z którym się on w pełni identyfikuje, i którego filmowe kwestie nagminnie cytuje, o tyle postać animowanego psa wyraża raczej postawę dystansu Hłaski do własnej osoby oraz jego groteskowe poczucie humoru, stanowiące niejako konieczny składnik powieści opartej na kreacji ludzkiego wizerunku, o czym wspomina w niej sam autor: „ucieczka w śmieszność i w groteskę stała się jedyną możliwością uniknięcia śmieszności: lepiej być błaznem grającym przed pełną salą niż Hamletem przemawiającym do pustych krzeseł” [Hłasko 1999: 165].

Pisarz konsekwentnie stosuje powyższą zasadę w całej swojej powieści. Dzięki temu wszystkie opowiadane przez niego historie i przytaczane dialogi, zarówno te prawdziwe, jak i te zmyślone, są pełne humoru nawet wtedy, gdy dotyczą raczej tragicznych, niż komicznych sytuacji. W ten sposób w Pięknych dwudziestoletnich rodzi się groteska, za pomocą której Hłasko łączy ze sobą elementy prawdziwego życia oraz filmu. Ta kategoria estetyczna służy mu między innymi do opisu bandyckich rabunków w stylu kina gangsterskiego z Bogartem, w jakich rzekomo brał udział. Szybko jednak wychodzi na jaw absurdalność i dziwaczność tego rodzaju sytuacji, bo nie dość, że nieodmiennie kończą się one katastrofami na miarę psa Goofy'ego, to jeszcze zabawny i kreskówkowy charakter mają pseudonimy współtowarzyszy pisarza w tych procederach, jak na przykład „Kaczor” [Hłasko 1999: 9]. Tymczasem prawdziwy humor i żart kryje się tam, gdzie Hłasko znajduje się najbliżej swego realnego życia. Dowodem potwierdzającym to stwierdzenie mogą być spisane przez niego scenki z udziałem babci jego kolegi w roli głównej, która pod wpływem regularnego oglądania wyświetlanych w kinie filmów całkowicie zmieniła swój język i sposób zachowania:

Po jakimś czasie babka kolegi zaczęła mówić stylem bohaterów filmu. Mówiła na przykład: „Ty, Marek. Kiedy mówisz do mnie, to trzymaj ręce opuszczone, bo może być nieprzyjemnościunia”. Kiedy inny kolega przychodzil, aby przywitać się z babką, babka odpowiadała: „Nie podaję nigdy ręki mańkutowi. To mi nieraz ocaliło życie”. Albo jeszcze inaczej: „Nie bądź taki równiak Mark. Pamiętaj, że przyjechałeś do Frisco, aby odpocząć i nabrać zdrowia” [Hłasko 1999: 73]. 
Autor Pięknych dwudziestoletnich nieustannie udowadnia zatem w swej powieści, że prawda, podobnie jak kłamstwo, wymaga niezbędnej retorycznej oprawy. Najwyraźniej to właśnie z tego przeświadczenia pisarza wynika nieprawdopodobieństwo, a czasem wręcz sztuczność dialogów w jego prozie [por. Galant 1996: 89], które najczęściej wzoruje on na swym ulubionym amerykańskim aktorze. Bogart stanowi bowiem dla Hłaski niepodważalny autorytet w kwestii gry ${ }^{7}$, jest traktowany przez niego jako uosobienie retoryki popkultury, jaka niewątpliwie charakteryzuje się silnym oddziaływaniem na różnorodne grupy odbiorców. Autor powieści, zafascynowany skutecznością tej metody interakcji, postanawia wykorzystać ją w swoim utworze na wszystkie możliwe sposoby. Nie ogranicza więc repertuaru swoich chwytów wyłącznie do prostego naśladownictwa i powielania osobowości oraz języka swojego idola, ale również samego siebie ogłasza on ekspertem $\mathrm{w}$ dziedzinie odgrywania różnych ról i z tej pozycji poucza w Pięknych dwudziestoletnich, jak należy się zachowywać w konkretnych sytuacjach, a w szczególności co w jakich okolicznościach należy mówić [por. Mulet 2012: 244]. Dla przykładu może tu posłużyć hipotetyczna rozmowa lekarza z pacjentem po próbie samobójczej, jaką Hłasko proponuje do odegrania wszystkim tym, którzy czują się przegrani życiowo ${ }^{8}$ :

Lekarz: - Więc cóż było ostatecznym powodem pańskiej decyzji odebrania sobie życia?

My: - Mogę panu to opowiedzieć. Ale to zajmie panu trzydzieści dwa lata. Tyle, ile ja żyję. Czy ma pan tyle czasu dla mnie?

Lekarz (łagodnie): - Proszę jednak odpowiedzieć, co było, że tak powiem, ostatecznym bodźcem. To bardzo ważne.

7 Zdaniem Jarzębskiego u Hłaski „Bogart, zdaje się dyktować reguły savoir-vivre'u obowiązujące w świecie utworów wydanych na emigracji [zalicza się do nich powieść Piękni dwudziestoletni wydana latem 1966 roku w Paryżu - K. Mulet]" [zob. Jarzębski 1984: 300-303].

${ }^{8}$ Hłasko ponownie odwołuje się tutaj do postaci losera, czyli „przegrywacza” [zob. Hłasko 1999: 115]. 
My: - Jeśli chodzi o ludzi takich jak ja, to nic nie jest ważne oprócz tego, aby nas (ludzi takich jak my) unikać. Ale spróbuję to panu powiedzieć. Kiedy umiera człowiek wolny, kończy się życie pełne niebezpieczeństw, pełne walki, pełne radości. Ale kiedy umiera nędzarz, kończy się tylko wstyd.

Mamy łzy w oczach. Powyższe zdanie ukradliśmy z filmu Spartakus. Kirk Douglas postanowił zginąć razem ze swymi ludźmi, ponieważ Krezus wykupił jego flotę, na której chciał z nimi zwiać; został tylko jeden statek; kapitan korsarzy namawia Spartakusa, aby wziął precjoza, Jean Simmons, i zaczął nowe życie; Douglas z oburzeniem odrzuca jego propozycję.

Kapitan korsarzy: - Dlaczego postanowiłeś zginąć, Spartakusie?

Kirk Douglas (po chwili zamyślenia, uśmiechając się z początku gorzko, następnie uśmiech zamienia się w wyraz wzniosłości): - Kiedy umiera człowiek wolny, kończy się życie etc. etc. Ale kiedy umiera niewolnik - kończy się tylko ból [Hłasko 1999: 116].

Przytoczony fragment Pięknych dwudziestoletnich w całości oddaje to, na czym polega scenariuszowy charakter tej powieści. Automitologia Hłaski to bowiem nie tylko klasyczna narracja opisowa, ale również rozbudowane dialogi opatrzone didaskaliami. Filmowy charakter tego utworu podkreślają dodatkowo dygresje jego autora poświęcone tematyce kina i aktorów. Co ciekawe, pisarz w swej prozie w zasadzie nie potrafi już zdobyć się na oryginalność [por. Jarzębski 1984: 306] i nawet wówczas, gdy obsadza samego siebie w roli autorytetu od spraw retoryki, korzysta przy tym ze sprawdzonych filmowych kwestii, umieszczając je po prostu w nowych kontekstach. Wyraża w ten sposób po raz kolejny swoje przekonanie o wtórności każdego ludzkiego gestu i słowa oraz o konwencjonalnym charakterze całej komunikacji, ale zarazem skazuje się na schematyzm [zob. Jarzębski 1984: 307; por. Mulet 2012: 246] i na uzależnienie od swoich popkulturowych idoli. Szczególne skupienie Hłaski na zagadnieniu kontaktów międzyludzkich powoduje, że jego utwory bywały już nieraz porównywane do prozy Witolda Gombrowicza9 , i choć Joanna

9 Między innymi przez Jarzębskiego [por. Jarzębski 1984: 307]. 
Pyszny pisze o bezzasadności tego rodzaju analogii [2007: XLIII], to wydają się one jednak ukazywać pewien związek pomiędzy autorem Pięknych dwudziestoletnich a twórcą Ferdydurke. Obu pisarzy łączy bowiem ze sobą podobny sposób postrzegania życia i literatury jako sceny, na której ludzie odgrywają określone role bądź wchodzą w określone formy.

Niemniej w powieści Hłaski na pierwszy plan wysuwa się ludyczna funkcja języka, o czym świadczy już sama popkulturowa tematyka tego utworu. Pisarzowi zależy przede wszystkim na zaciekawieniu nim czytelnika, dlatego zamiast typowej biografii proponuje wymyśloną legendę, która tylko czasami ociera się o rzeczywistość. Przedstawione w niej historie opowiedziane są w stylu mowy ulicy, prostych ludzi i nieoficjalnych sytuacji komunikacyjnych [zob. Pyszny 2007: XXXVIII], co sprzyja jej uniwersalizmowi i dostępności dla przeciętnego odbiorcy. Jednak autor Pięknych dwudziestoletnich nie poprzestaje na tym i włącza do swej powieści także wypowiedzi o charakterze brutalnym, czy wręcz wulgarnym w celu dodatkowego wzmocnienia swojej retorycznej ekspresji. Tego rodzaju stylistyka pojawia się najczęściej w kontekście przestępczego półświatka, choć Hłasko równocześnie udowadnia, że nawet gangster siedzący $\mathrm{w}$ więzieniu może być człowiekiem wrażliwym i sentymentalnym, gotowym do zapewnienia rozrywki współosadzonym włamywaczom i sutenerom:

Dobrze jest, jeśli widziałeś dużo filmów i umiesz je odgrywać. Jeśli masz dobrą pamięć, to odgrywaj Przeminę̨to z wiatrem, Waterloo Bridge i Casablanca; nie odgrywaj natomiast filmów gangsterskich i policyjnych, gdyż są to prawie bez wyjątku filmy idiotyczne, z wyjątkiem The Aspalth Jungle - ale niech Bóg broni, aby ci przyszła ochota odegrać Rififi. Pamiętaj o tym, że zrobienie dobrego i prawdziwego filmu szpiegowskiego lub policyjnego jest niemożliwe, ponieważ, aby być dobrym szpiclem, trzeba umieć zgubić się wśród innych ludzi; a nie może tego dokonać człowiek taki jak Gary Cooper czy Sean Connery. Trzymaj się dramatu obyczajowego i filmów awanturniczych; więźniowie lubią Eddie Constantine’a; jego filmy odgrywać najłatwiej, ponieważ mało różnią się między sobą [Hłasko 1999: 132-133]. 
W ten sposób po raz kolejny okazuje się, że gra jest niezastąpionym narzędziem we wszelkich kontaktach międzyludzkich, zarówno tych najbardziej codziennych i prozaicznych, jak i tych zupełnie niezwykłych czy skomplikowanych. Retoryka popkultury stanowi bowiem uniwersalny schemat zachowań i wypowiedzi, który odpowiednio wykorzystany, przynosi zaskakująco dobre rezultaty w kwestii oddziaływania na drugiego człowieka ${ }^{10}$. Hłasko posługuje się nim w Pięknych $d w u d z i e s t o l e t n i c h$ poprzez ujawnienie swojej fascynacji filmami i aktorami, a w szczególności poprzez naśladownictwo jednych i drugich. Parafrazuje więc w swej powieści kinowe dialogi oraz upodabnia się do swych idoli pozornie wcielając się w coraz to nowe role i postaci. W ostatecznym rozrachunku okazuje się jednak, że każdy z wykreowanych w ten sposób bohaterów to w rzeczywistości jedna i ta sama osoba, a mianowicie sam pisarz, odsłaniający w miarę zapotrzebowania swoje różne twarze.

\section{Bibliografia}

Galant J. [1996], Marek Hłasko, Dom Wydawniczy Rebis, Poznań.

Hłasko M. [1999], Piękni dwudziestoletni, Wydawnictwo Da Capo, Warszawa. Jarzębski J. [1984], Hłasko - retoryka grzechu i nawrócenia, [w: ] tegoż, Powieść jako autokreacja, Wydawnictwo Literackie, Kraków.

Kurpiewski L. [1986], Wstęp, [w:] Hłasko M., Utwory wybrane, t. 1, Czytelnik, Warszawa.

Mulet K. [2012], Analiza mimetyczna Pięknych dwudziestoletnich Marka Hłaski, [w:] Poza monogamią, Potkański J., Pruszczyński R. (red.), Dom Wydawniczy ELIPSA, Warszawa.

Pyszny J. [2007], Wstęp, [w: ] Hłasko M., Pierwszy krok w chmurach. Następny do raju, Pyszny J. (oprac.), Zakład Narodowy im. Ossolińskich, Wrocław, BN I, 295.

Wasilewski P. [1991], Niespetnione tęsknoty outsidera, [w:] Hłasko nieznany, Wasilewski P. (oprac.), Krajowa Agencja Wydawnicza, Kraków.

Wielopolski W. [1996], Młoda proza polska przełomu 1956, Zakład Narodowy im. Ossolińskich, Wrocław.

${ }^{10}$ Hłasce posłużyła przede wszystkim w procesie autokreacji, pomogła mu jeszcze za życia stworzyć legendę pisarza-buntownika [por. Mulet 2012: 239]. 